\title{
Perbandingan Bentuk Kelembagaan Pengelola Nama Domain di Indonesia dengan Lembaga Pengelola Nama Domain di Beberapa Negara
}

\author{
Helni Mutiarsih Jumhur27
}

\begin{abstract}
Abstrak
Lembaga pengelolaan dan pendaftaran nama domain di Indonesia dilakukan oleh lembaga yang didirikan oleh masyarakat atau pemerintah. Pengelolaan dan pendaftaran nama domain di Indonesia dilakukan oleh lembaga yang dinamakan PANDI (Pengelola Nama Domain Indonesia). PANDI merupakan organisasi nirlaba yang dibentuk oleh komunitas Internet Indonesia bersama pemerintah pada 29 Desember 2006 untuk menjadi registry domain (.id). Dalam tulisan ini akan dikemukakan beberapa perbandingan lembaga pengelola dan pendaftaran nama domain di beberapa negara yaitu, Australia, Singapura, dan Malaysia. Alasan dipilihnya negara-negara tersebut karena telah terbentuknya institusi dan peraturan yang komprehensif pada manajemen dan pendaftaran nama domain. Studi perbandingan ini bertujuan untuk menemukan bentuk nama lembaga yang dapat menjadi acuan dalam menentukan model lembaga negara serupa di Indonesia yang dapat mengatur manajemen domain pendaftaran yang tepat dan sesuai dengan undang-undang terkait. Kesimpulan dari penelitian ini adalah model lembaga pengelolaan dan pendaftaran nama domain yang paling tepat dan dapat digunakan sebagai acuan adalah lembaga pengelolaan dan pendaftaran nama domain di Australia (.AuDA).
\end{abstract}

Kata kunci: pendaftaran nama domain, pengelola nama domain Indonesia, lembaga pengelola nama domain, PANDI, .AuDA.

\section{Comparative Study of the Institutional Forms of Domain Name Management between Indonesia and Other Countries}

\begin{abstract}
Domain Name Management is conducted by the institute founded by people or institutions established by the government. Management and the registration of Domain Name in Indonesia is conducted by an agency called PANDI (Domain Name Management of Indonesia). PANDI is a non-profit organization formed by the Indonesian Internet community and the government on December 29, 2006 to become the domain registry (.id) on June 29, 2007. This paper will put forward some comparisons of Domain Name Managements in several countries, namely: Australia, Singapore, and Malaysia. These countries are chosen because they already have the institutions and comprehenshive regulations on the management and registration of domain names. The aim of this study is to find the form of the name of the
\end{abstract}

27 Dosen pada Fakultas Economic and Business School, Telkom University, mutiarsih@gmail.com, S.H. (Universitas Islam Bandung), M.H. dan Dr. (Universitas Padjadjaran). 
Helni Mutiarsih Jumhur: Perbandingan Bentuk Kelembagaan Pengelola Nama Domain di Indonesia dengan Lembaga Pengelola Nama Domain di Beberapa Negara

institution that can become a reference in determining the Indonesian State agency model management domain name registration appropriate and in accordance with the Indonesian legislation. This article concluded that the most appropriate model of institutions to be used as a reference is a model of Domain Name Management in Australia (AuDA).

Keywords: domain name registration, Indonesian domain name management, domain name management institution, PANDI, .AuDA.

\section{A. Pendahuluan}

Peraturan perundang-undangan yang menjadi dasar dari pengelolaan nama domain, istilah nama domain telah ada pada Undang-Undang Nomor 11 Tahun 2008 tentang Informasi dan Transaksi Elektronik (UU ITE) yang menyebutkan bahwa nama domain merupakan alamat seseorang atau badan usaha di internet yang dapat digunakan untuk akses informasi. Bentuk dari lembaga pendaftaran nama domain dapat berbentuk masyarakat atau badan hukum. Sementara itu dalam Peraturan Pemerintah Nomor 82 Tahun 2012 tentang Sistem dan Transaksi Elektronik, pengelola nama domain ada dua pihak: pertama, registry nama domain yang merupakan penyelenggara yang bertanggung jawab dalam pengelolaan, pengoperasian dan pemeliharaan; kedua, registrar nama domain orang, badan usaha, dan masyarakat yang menyediakan pendaftaran nama domain.

Registry nama domain wajib ditetapkan oleh menteri dan registrar nama domain selain oleh instansi wajib terdaftar pada menteri. Seluruh registry dan registrar nama domain memiliki beberapa kewajiban dalam mengelola nama domain yaitu: pertama, pengelolaan nama domain harus dijalankan dengan akuntabel; kedua, pendaftaran nama domain harus dilaksanakan dengan asas pendaftaran pertama. Pengawasan pengelolaan nama domain dilakukan oleh menteri. Menurut teori negara hukum, pengaturan nama domain harus sesuai dengan ketentuan perundangundangan yang berlaku bahwa lembaga pengelolaan dan pendaftaran nama domain di Indonesia didirikan oleh pemerintah dan atau masyarakat dengan tujuan jika terjadi ketidakmampuan lembaga pengelola nama domain yang didirikan oleh masyarakat maka pemerintah dapat mengambil alih. Berdasarkan peraturan perundang-undangan, fungsi pemerintah dalam pengelolaan dan pendaftaran nama domain adalah memberikan perlindungan dan rasa aman kepada pengguna atau pemilik nama domain di Indonesia. Pembentukan lembaga pengelola nama domain di Indonesia diinisiasi oleh pihak masyarakat internet yaitu lembaga Pusilkom UI yang berhasil mendaftarkan Budi Rahardjo sebagai kode negara domain tingkat

1 ccTLD sudah di re-delegasi Budi Rahardjo kepada M Niel el Himam, atas persetujuan lembaga internasional ICANN. 
Helni Mutiarsih Jumhur: Perbandingan Bentuk Kelembagaan Pengelola Nama Domain di Indonesia dengan Lembaga Pengelola Nama Domain di Beberapa Negara

atas/country code top-level domain (ccTLD) sehingga pada tahun 1998 berdirilah lembaga nirlaba Pengelola Nama Domain Indonesia (PANDI) dan pada tahun 2006 menjadi registry domain .id. Pada 29 Juni 2007, pemerintah melalui Departemen Komunikasi dan Informatika RI (DEPKOMINFO) secara resmi menyerahkan pengelolaan seluruh domain internet Indonesia kepada PANDI, selain go.id dan mil.id. Penyerahan pengelolaan domain .id ini dituangkan dalam Berita Acara Penyerahan Pengelolaan Domain .id No BA 343/DJAT/MKOMINFO/6/2007 dari Dirjen Aptel ke PANDI. Saat ini PANDI mengelola secara penuh domain co.id, biz.id, my.id, web.id, or.id, sch.id, ac.id, dan net.id, serta membantu Pemerintah Republik Indonesia mengelola domain go.id dan mil.id.

Pengelolaan nama domain di Indonesia diatur dalam UU ITE serta peraturan di bawahnya, ${ }^{2}$ yang lahir setelah lembaga pengelola nama domain Indonesia sudah berdiri sehingga dalam kenyataannya belum ada kesesuaian antara peraturan perundang-undangan yang ada dengan lembaga pengelola nama domain yang sudah berdiri. Hal ini mengakibatkan belum jelas dan belum sesuainya bentuk lembaga pengelola nama domain di Indonesia sehingga dibutuhkan suatu perbandingan bentuk lembaga pengelola nama domain dengan negara-negara lain, di antaranya Australia, Malaysia, dan Singapura. Pada tulisan ini, Penulis menggunakan metode penelitian berupa:

1. Yuridis normatif kualitatif dengan menggunakan data sekunder berupa peraturan perundang-undangan guna mengharmonisasi peraturan perundangundangan baik secara vertikal maupun horizontal guna mengetahui permasalahan yang terjadi, perbandingan dalam bentuk-bentuk lembaga pengelola, dan pendaftaran nama domain;

2. Analisis data yang digunakan dalam penelitian ini adalah analisis data yuridis kualitatif dengan menggunakan daya abstrak dan penafsiran hukum selanjutnya hasil analisis dibuat dalam bentuk uraian (deskripsi). ${ }^{3}$

\section{B. Bentuk-Bentuk Lembaga Pengelola dan Pendaftaran Nama Domain di Australia, Singapura, dan Malaysia}

Dalam tulisan ini akan dikemukakan beberapa perbandingan lembaga pengelola dan pendaftaran nama domain di beberapa negara yaitu, Australia, Singapura, dan Malaysia. Alasan dipilihnya ketiga negara tersebut dikarenakan ketiganya telah memiliki lembaga dan peraturan yang komprehensif tentang pengelolaan dan pendaftaran nama domain di masing-masing negaranya.

2 Pengaturan nama domain diatur dalam UU ITE serta peraturan di bawahnya yaitu Peraturan Pemerintah Nomor 82 Tahun 2012 tentang Sistem dan Transaksi Eelektronik (PPSTE) dan Peraturan Menteri Kominfo Nomor 23 tahun 2013 tentang Pengelolaan Nama Domain.

3 Ronny Hanitijo Soemitro, (1994), Metodologi Penelitian Hukum dan Jurumetri, Jakarta: Ghalia, hlm. 26-27. 
Helni Mutiarsih Jumhur: Perbandingan Bentuk Kelembagaan Pengelola Nama Domain di Indonesia dengan Lembaga Pengelola Nama Domain di Beberapa Negara

\section{Lembaga Pengelola Nama di Australia: The Australian Domain Name Administrator (.AuDA)}

Dimulai dari negara Australia yang memiliki sistem hukum Anglo Saxon, ${ }^{4}$ pengelolaan nama domain di Australia telah dilakukan dengan sangat teratur karena ada lembaga pengelola nama domain yaitu AuDA yang merupakan badan independen atau selfregulatory body untuk nama domain .au..$^{5}$ Pada bulan Desember 2000, Pemerintah Australia secara resmi mengesahkan AuDA sebagai lembaga yang tepat untuk mengelola ruang domain .au. selain sebagai pengelola nama domain, AuDA merupakan ccTLD bagi pengelolaan nama domain di Australia. AuDA telah ditunjuk oleh ICANN sebagai lembaga pengelola nama domain yang dikelola dengan baik dan efektif.

Pengelolaan nama domain AuDA tidak melakukan sistem pendaftaran secara langsung kepada pendaftar tetapi dengan memberikan hak pengelolaan kepada registrar dengan perjanjian lisensi dan registrar ini harus memenuhi akreditasi yang telah diatur dalam kebijakan yang dikeluarkan AuDA, selanjutnya registrar akan memberikan hak untuk melakukan pendaftaran kepada pemohon dan pemohon harus menunjuk pihak registrar yang menjadi pengelola nama domain yang diajukan.

\section{a. Kelembagaan Pengelola Nama Domain di Australia : .AuDA di Australia}

Pengaturan nama domain di Australia saat ini ada di bawah kendali $A u$ Domain Administration Ltd. (AuDA) .au. ${ }^{6}$ Domain Administration Ltd. (AuDA) adalah badan independen atau self-regulatory body untuk nama domain .au. Pada bulan Desember 2000, Pemerintah Australia secara resmi mengesahkan AuDA sebagai lembaga yang tepat untuk mengelola ruang domain (.au). Pemerintah memiliki wewenang terhadap nama-nama domain di bawah pengaturan Undang-Undang Telekomunikasi Tahun 1997. Pada bulan Oktober 2001, ICANN mengakui AuDA sebagai operator yang tepat untuk au berdasarkan perjanjian sponsorship. AuDA adalah administrator untuk ccTLD Australia (.au) dan domain tingkat kedua yang terkait. Pada tahun 2000, AuDA telah berhasil dikembangkan sebagai efektif administrator .au dan mendapat penghargaan sebagai contoh ccTLD yang dikelola dengan baik.

AuDA adalah badan independen atau self-regulatory body dan ccTLD untuk pengelolaan nama domain di Australia yang diatur berdasarkan aturan yang masih berada di bawah kendali Undang-Undang Telekomunikasi Australia. AuDA tidak melakukan pendaftaran nama domain secara langsung kepada pendaftar tetapi menunjuk pihak lain yaitu registry sebagai reseller dan merupakan perusahaan yang diberikan izin oleh AuDA untuk melakukan pendaftaran nama domain dan

4 Rinda Amalia, "Sistem Hukum Singapura" http://www.google.com/ rindaamalia.dosen.narotama.ac.id/Ffiles/F2013/F07/FKuliah-10-Sistem-Hukum-Singapura.

5 AudA, “AudA History”, http://www.ausregistry.com.au/role-of-the-registry, diunduh 20 Oktober 2013.

6 AudA, "About AudA", http://www.AudA.org.au/about-AudA/, diunduh 15 Juli 2013. 
Helni Mutiarsih Jumhur: Perbandingan Bentuk Kelembagaan Pengelola Nama Domain di Indonesia dengan Lembaga Pengelola Nama Domain di Beberapa Negara

perusahaan tersebut harus memenuhi standar akreditasi yang telah ditetapkan oleh peraturan kebijakan AuDA. Registrar yang telah terakreditasi diberikan lisensi sebagai reseller kepada registrant. Registrant merupakan pihak pengelola nama domain bagi para pendaftar.

\section{b. Fungsi dan Peran .AuDA sebagai Pengelola Nama di Australia}

AuDA adalah administrator untuk .au dan domain tingkat kedua yang terkait. ${ }^{7}$ AuDA berkomitmen untuk mempertahankan posisinya sebagai salah satu dunia manajer terbaik dalam praktik ccTLD. Rencana ini menetapkan pekerjaan yang akan dibutuhkan selama tiga tahun ke depan agar.AuDA dapat mempertahankan posisinya dengan cara mendukung secara sehat dalam lingkungan berkelanjutan yang bersifat self-regulatory di dunia yang cepat berubah ini. Peran AuDA antara lain:

1) Mengembangkan dan mengimplementasikan kebijakan nama domain;

2) Lisensi 2DL registry operators;

3) Akreditasi dan license registrars;

4) Menerapkan perlindungan dan keamanan consumer;

5) Memfasilitasi .au Dispute Resolution Policy; dan

6) Mewakili domain .au di ICANN dan forum internasional lainnya;

Pada awalnya .au dialokasikan oleh Jon Postel, operator dari IANA ke Kevin Robert Elz dari Melbourne University pada tahun $1986 .{ }^{8}$ Lima tahun kemudian sekitar tahun 1990-an, industri internet Australia membentuk badan independen atau selfregulatory body yang dinamakan untuk mengoperasikan ccTLD. Tantangan yang dihadapi AuDA sangat signifikan. Dalam pengelolaan .au berbeda dengan domain tingkat dua, sebelumnya telah didelegasikan kepada organisasi yang berbeda beberapa di antaranya dioperasikan sistem registry mereka sendiri. Namun sebagian besar nama domain dengan kode negara .au dipertahankan dalam sistem registry kuno yang tidak aman sehingga dibutuhkan pergantian sistem.

Pada tahun 2001 AuDA mengeluarkan tender terbuka bagi pihak yang berkepentingan untuk mengajukan tawaran untuk menerapkan dan mengoperasikan sistem registry terbaik untuk berbagai domain tingkat dua dalam .au. AusRegistry berhasil melakukan konsolidasi sistem registry yang terbuka untuk semua domain .au tingkat dua. ${ }^{9}$ Pada tahun 2005, setelah tender lain yang terbuka, AusRegistry sekali lagi terpilih untuk menjadi penyelenggara registry tingkat dua untuk periode empat tahun yang dimulai tanggal 1 Juli 2006 sampai tahun 2009, AuDA mengumumkan

7 AudA, "Strategc Plan", http://www.AudA.org.au/about-AudA/our-org/strategic-plan/,diunduh 20 September 2012.

8 AudA, "History of the .au TLD",http://www.ausregistry.com.au/role-of-the-registry, diunduh 20 Oktober 2013.

9 Ausregistry.com.au is a $3 L D$, Australian country code Domain Name. AusRegistry offers the following Domain types within the auccTLD. 
Helni Mutiarsih Jumhur: Perbandingan Bentuk Kelembagaan Pengelola Nama Domain di Indonesia dengan Lembaga Pengelola Nama Domain di Beberapa Negara

bahwa Perjanjian Lisensi sebagai Registry.au melalui perjanjian lisensi Registry dengan AusRegistry sampai dengan 2014.

Pada masa kerja sebagai registry operator, ARI registry bekerja dengan AuDA untuk menumbuhkan .au top level domain dengan strategis memperluas jaringan dan membantu memperkuat registry operator nama domain .au untuk menumbuhkan dan mendaftarkan. Dengan demikian, sejak AusRegistry menjadi registry operator dari nama domain .au, jumlah pendaftaran telah berkembang dari hanya lebih dari 270.000 pada tahun 2002 menjadi lebih dari 2,2 juta pada tahun 2011, dengan pertumbuhan $25 \%$ rata-rata pendaftaran dari tahun ke tahun. AusRegistry juga menciptakan dan memperluas jaringan registrar ke AuDA terakreditasi.

\section{c. Prosedur Pendaftaran Lembaga Nama Domain AuDA di Australia}

Pendaftar yang ingin mengajukan pendaftaran nama domain com.au, net.au, org.au, asn.au, atau id.au, dapat memilih registrar pendaftaran dan mengikuti proses aplikasi mereka. ${ }^{10}$ Beberapa registrar memberikan pelayanan langsung kepada masyarakat, untuk lebih jelas dapat melihat daftar registrar AuDA yang sudah terakreditasi, dan jika ingin mengajukan pendaftaran gov.au domain name, Pendaftar harus mengikuti proses yang tercantum pada website http://www.domainname.gov.au/ dan untuk mengajukan nama domain edu.au domain, pendaftar dapat mengikuti petunjuk yang tercantum dalam website http://www.domainname.edu.au/. Langkah selanjutnya, pendaftar perlu menghubungi registrar yang akan mengelola nama domain. Registrar akan memberikan layanan di antaranya: memperbaharui rincian pendaftar, delegasi nama server, dan layanan terkait lainnya. Beberapa registrar juga memberikan layanan hosting, administrasi yang tidak berada di bawah wewenang AuDA dan untuk mengetahui data dare registrar yang pendaftar pilih silakan lihat layanan WHOIS yang ada di website AuDA. Sebagai pendaftar nama domain, pendaftar memiliki hak-hak sebagai berikut:

1) memilih registrar yang diinginkan atau reseller;

2) jika menggunakan reseller, pendaftar harus tahu bahwa registrar yang dipilih merupakan registrar terdaftar;

3) memahami secara sadar semua materi dan semua biaya untuk registrasi nama

10 Domain Name is an addressing construct used for identifying and locating computers on the Internet. Domain Names provide a system of easy-to-remember Internet addresses, which can be translated by the Domain Name System (DNS) into the numeric addresses (Internet Protocol(IP) numbers) used by the network. For example: IP Address: 202.65.12.105 maps to the ausregistry.com.au Domain Name. Domain Names at the same level of the hierarchy must be unique. Thus, for example, there can only be one .com.au at the top-level of the hierarchy, and only one ausregistry.com.au at the next level of the hierarchy. Domain Names must:
a) be at least 2 characters long;
b) contain only letters (a-z), numbers (0-9) and hyphens (-), or a combination of these;
c) start and end with a number or a letter, not a hyphen; and
d) not contain hyphens in the third and fourth position (eg. ab--cd.com.au). 
Helni Mutiarsih Jumhur: Perbandingan Bentuk Kelembagaan Pengelola Nama Domain di Indonesia dengan Lembaga Pengelola Nama Domain di Beberapa Negara

domain, sebelum mendaftarkan nama domain pendaftar;

4) mentransfer nama domain pendaftar antara registrar dan reseller;

5) memiliki hak untuk mengajukan keluhan kepada registrar dan jika tidak puas dengan hasilnya, maka pendaftar dapat mengajukan keluhan kepada AuDA secara langsung.

d. Lembaga Sengketa Nama Domain di .AuDA: .au Dispute Resolution Policy $(\text { auDRP) })^{11}$

Tujuan auDRP ini adalah untuk memberikan alternatif yang lebih murah dan cepat untuk resolusi perselisihan antara pendaftar dari nama domain .au dan hak bersaing dalam nama domain .auDispute Resolution Policy (auDRP), termasuk aturan-aturan prosedural .auDRP ini dimulai pada tanggal 1 Agustus 2002 asn.au, com.au, id.au, net.au dan nama domain org.au. ${ }^{12}$ Tanggal 19 Juni 2003 auDRP ini diperpanjang untuk menutupi nama domain edu.au. auDRP ini merupakan adaptasi dari Uniform Dispute Resolution Policy (UDRP) yang diatur oleh ICANN sehubungan dengan Top Level Domain dunia (gTLD). ${ }^{13}$.auDRP ini disusun oleh AuDA's Dispute Resolution Working Group. Dari dimulainya sistem auDRP tahun 2002 sampai dengan April 2007, telah dikeluarkan 80 keputusan, 48 (atau 60\% dari keputusan) dari keputusan ini mengakibatkan perintah untuk transfer nama domain yang disengketakan.

\section{Lembaga Pengelola Nama di Singapura: Singapore Network Information Centre (SGNIC)}

Singapura merupakan negara bekas jajahan Inggris, maka dapat diketahui bahwa Singapura mempunyai sistem hukum, yaitu Common Law System atau Anglo Saxon, detail, penerapan dan pelaksanaannya disesuaikan dengan kebutuhan dan kebijakan negara. ${ }^{14}$ Bahkan saat ini terdapat pengakuan yang lebih besar pada yurisprudensi lokal di dalam perkembangan common law di Singapura. Jadi, lebih menitikberatkan situasi dan kondisi yang ada dalam negara Singapura. Pengelolaan nama domain di Singapura berada di bawah The Infocom Development Authority of Singapore (IDA). ${ }^{15}$

11 Mark Bender, "What's in a Name: Domain Name Disputes Involving Trademarks in Australia", http://papers.ssrn.com/sol3/papers.cfm?abstract_id=1091066, diunduh 15 Juli 2013.

12 au Dispute Resolution Policy (auDRP), http://www.AudA.org.au/policies/current policies/201005/http://www.AudA.org.au/policies/current-policies/2010-05/.

13 auDRP 1. Background, I.3. The auDRP is an adaptation of the Uniform Dispute Resolution Policy (UDRP) administered by the Internet Corporation for Assigned Names and Numbers (ICANN) with respect to the global Top Level Domains ( $g T L D s)$. The auDRP differs from the UDRP in two main respects:

a) to take account of the policy rules that apply to au domain names, that do not apply to gTLD domain names; and

b) to address practical constraints that have become apparent since arbitrations under the UDRP began in 1999.

$14 \mathrm{Ibid}, \mathrm{hlm} .3$.

15 The Infocomm Development Authority of Singapore (IDA), http://www.ida.gov.sg/,_diunduh 12 Juli 2012. 
Helni Mutiarsih Jumhur: Perbandingan Bentuk Kelembagaan Pengelola Nama Domain di Indonesia dengan Lembaga Pengelola Nama Domain di Beberapa Negara

IDA merupakan badan hukum milik Pemerintah Singapura yang didirikan pada saat terjadi merger antara the National Computer Board (NCB) dan Telecommunication Authority of Singapore (TAS), yang bertujuan untuk mengelola perkembangan teknologi informasi dan telekomunikasi di Singapura. Lembaga pengelola nama domain di Singapura adalah Singapore Network Information Centre (SGNIC). Meskipun SGNIC merupakan lembaga nirlaba, tetapi lembaga ini berada di bawah IDA sehingga pengelolaan nama domain terencana dan terkendali dengan baik karena Pemerintah Singapura dapat terlibat langsung dalam proses regulasi pengelolaan nama domain. Hal yang paling menarik untuk dipelajari adalah SGNIC telah memiliki lembaga sengketa nama domain yang telah mempunyai sistem yang sangat teratur sehingga telah berhasil menyelesaikan sengketa nama domain yang membuat para pemilik nama domain merasa aman.

\section{a. Kelembagaan Pengelola Nama Domain di Singapura: SGNIC}

SGNIC dibentuk pada bulan Oktober 1995 dengan tujuan utama pemberian ruang internet nama domain di Singapura serta menyediakan forum bagi para Internet Service Provider lokal dan badan pengawas untuk membahas masalah yang berkaitan dengan administrasi yang efisien dari layanan internet di Singapura. ${ }^{16}$ Pada Juni 1997, SGNIC didirikan sebagai perusahaan terbatas swasta yang dimiliki sepenuhnya oleh NCB. SGNIC kemudian dipindahkan ke IDA ketika pemerintah menggabungkan NCB dan Otoritas Telekomunikasi Singapura pada tanggal 1 Desember $1999 .{ }^{17}$ SGNIC bertindak sebagai registry untuk SGTop-Level Domain dan mengakreditasi registrar untuk menjalankan fungsi registrar dalam menyediakan pendaftaran untuk SG ccTLD kepada pendaftar. ${ }^{18}$

\section{b. Fungsi dan Peran SGNIC sebagai Pengelola Nama di Singapura}

Singapore Network Information Centre (SGNIC) Private Limited adalah registry nasional nama domain .sg di Singapura. ${ }^{19}$ Sebagai registry, SGNIC beroperasi dan mengontrol tingkat atas sistem nama domain Internet .sg dan mengelola pendaftaran (a) nama domain tingkat ketiga di bawah-tingkat kedua.com, .org, .net, .edu, .gov. dan per domain, dan (b) nama domain tingkat kedua di bawah domain toplevel.sg. ("SLDs").

16 SGNIC, "History", http://www.sgnic.sg/page/history-sgnic, diunduh 17 Juli 2013.

17 The Infocomm Development Authority of Singapore (IDA),http://www.ida.gov.sg/, The Infocomm Development Authority of Singapore (IDA), a statutory board of the Singapore Government, was formed on 1 December 1999 when the government merged the National Computer Board (NCB) and Telecommunication Authority of Singapore (TAS), as a result of a growing convergence of information technology and telephony. IDA aims to grow Singapore into a dynamic global infocomm hub and to infocomm for Singapore's economic and social development.

18 SGNIC, "Structure SGNIC", http://www.sgnic.sg/page/structure-sgnic, diunduh $17 \mathrm{Juli} 2013$.

19 Registration Policies, Procedures and Guidelines (RPPG), SGNIC REGISTRATION POLICIES, PROCEDURES AND GUIDELINES 
Helni Mutiarsih Jumhur: Perbandingan Bentuk Kelembagaan Pengelola Nama Domain di Indonesia dengan Lembaga Pengelola Nama Domain di Beberapa Negara

SGNIC merumuskan dan melaksanakan kebijakan yang berkaitan dengan .sg domain ruang nama dan memiliki kewenangan dan kapasitas untuk masuk ke dalam perjanjian dengan entitas apapun untuk mengelola pendaftaran, pemeliharaan, dan operasi lainnya dari nama domain .sg SGNIC telah terakreditasi sejumlah pendaftar ("pendaftar terakreditasi"), untuk pendaftaran dan operasi lainnya seperti update, transfer, penghapusan, dan pembaharuan pemulihan dari nama domain .sg, com.sg, .org.sg, .net.sg, edu.sg, dan.per.sg. Sebuah daftar pendaftar terakreditasi SGNIC yang tersedia di http://www.sgnic.sg. SGNIC mungkin menunjuk registrar ("registrar yang ditunjuk") untuk mendaftar dan memelihara nama domain sg. (nama domain gov.sg misalnya). Dalam dokumen ini, referensi untuk pendaftar termasuk pendaftar terakreditasi (dan reseller dan agen mereka).

\section{c. Prosedur Pendaftaran Domain Name di SGNIC}

Dalam proses pengajuan pendaftaran nama domain, SGNIC memiliki aturan kebijakan Registration Policies, Procedures and Guidelines (RPPG). ${ }^{20}$ Dokumen ini menetapkan Kebijakan Pendaftaran, Prosedur, dan Pedoman yang berkaitan dengan nama domain .sg di Singapura yang saat ini diterapkan oleh SGNIC salah satunya adalah domain .sg. Nama-nama yang berisi karakter non-Latin (an "Internasionalisasi Nama Domain" atau "IDN") dan versi yang berbeda dari IDN yang sama terkait dengan itu ("Varian"). Pada dokumen ini, nama domain adalah IDN, referensi untuk "nama domain" meliputi referensi ke varian IDN. Dokumen ini, sebagaimana dapat diubah dari waktu ke waktu oleh SGNIC, berlaku untuk kedua pendaftar dan harus dibaca hubungannya dengan perjanjian lain yang relevan antara masing-masing pihak dan SGNIC. SGNIC ${ }^{21}$ menerima pendaftaran nama domain di bawah top-level sg. dan nama domain tingkat kedua terbuka: .com.sg, .org.sg, .net.sg, .edu.sg, dan .per.sg.

Biaya yang timbul dalam proses pendaftaran telah diberitahukan dalam lampiran peraturan kebijakan ini. SGNIC berhak mengubah perjanjian Registry, RPPG ini dengan pemberitahuan 30 hari dari tanggal perubahan tersebut dan akan di-posting di website yang sama yaitu SGNIC di http://www.nic.net.sg. ${ }^{22}$ Perjanjian Registrant dianggap telah diubah pada jangka waktu berakhirnya tanggal pemberitahuan tersebut dan akan mengikat terhadap registrar dan registrant.

\section{d. Lembaga Penyelesaian Perselisihan Nama Domain di Singapura: Singapore Domain Name Dispute Resolution Policy (Singapore Domain Dispute Policy) di SGNIC}

SGNIC mengadopsi SDRP sebagai kebijakan otoritas untuk kode negara tingkat atas

20 Registration Policies, Procedures and Guidelines (RPPG) ini diatur oleh dan harus ditafsirkan sesuai dengan hukum Republik Singapura Version 4, May 2012 Mapletree Business City.

21 Singapore Network Information Centre (SGNIC) Pte Ltd.

$22 \mathrm{Ibid}, \mathrm{hlm} .3$; Categories and Eligibility Criteria for .SG Domain Names, (3.1-3.8), hlm 3-6. 
Helni Mutiarsih Jumhur: Perbandingan Bentuk Kelembagaan Pengelola Nama Domain di Indonesia dengan Lembaga Pengelola Nama Domain di Beberapa Negara

domain Singapura. ${ }^{23}$ SDRP adalah kebijakan yang menetapkan kerangka pengaturan tentang bagaimana perselisihan antara registrant dan pihak (selain SGNIC) atas pendaftaran dan penggunaan nama domain .sg milik registrant diselesaikan. Setiap pihak yang berpartisipasi dalam tindakan administratif harus mematuhi syarat dan kondisi dari SDRP tersebut. Tindakan akan dilakukan sesuai dengan peraturan dan aturan tambahan dari SDRP tersebut. Dalam menjalankan proses peradilan melalui SDRP terdapat mekanisme yang tertuang di dalamnya, yaitu suatu kebijakan yang dibuat oleh SGNIC sebagai pedoman dalam menyelesaikan sengketa nama domain.

\section{Lembaga Pengelola Nama Domain di Malaysia: Malaysia Registrar of My Domain (MyNIC)}

Malaysia adalah negara dengan sistem hukum sama dengan Singapura karena keduanya merupakan bekas jajahan Inggris, tetapi Malaysia menganut sistem federal yang terdiri atas negara-negara bagian. ${ }^{24}$ Singapura pernah menjadi bagian dari negara bagian Malaysia tetapi melepaskan diri menjadi negara mandiri. Pengelolaan nama domain di Malaysia dilakukan oleh lembaga yang dinamakan Malaysia Registrar of My Domain (MyNIC) yang merupakan sebuah badan yang berada di bawah Departemen Komunikasi dan Multimedia Malaysia (KKMM) dan diatur oleh Komunikasi Malaysia dan Komisi Multimedia (MCMC). Malaysia dipilih sebagai referensi dalam perbandingan sistem pengaturan nama domain karena dalam pengaturan nama domain di Malaysia, pihak pemerintah dan pihak swasta berhasil melakukan pengelolaan nama domain secara harmonis sehingga nama domain yang dianggap sebagai subjek yang strategis dapat terkendali dan terlindungi dengan baik oleh pemerintah. Hal ini merupakan contoh yang baik dalam hal perlindungan hukum yang diberikan pemerintah kepada para pemilik nama domain dalam melakukan pendaftaran nama domain.

\section{a. Kelembagaan MyNIC di Malaysia}

MyNIC (badan hukum Berhad MyNIC; Pendaftaran Perusahaan No: 735031-H) adalah lembaga di bawah Ministry of Science, Technology, and Innovation (MOSTI) dan diatur oleh Malaysian Communication and Multimedia Commission (MCMC). ${ }^{25}$ MyNIC adalah satu-satunya administrator untuk alamat web yang berakhir dengan .my di Malaysia. Sebagai nama domain tingkat nasional, MyNIC merupakan organisasi

$23 \mathrm{Ibid}$, hlm. 14; Fees, hlm 16; SGNIC, "Singapore Domain Name Dispute Resolution Policy (SDRP) Policy", http://www.sgnic.sg/sites/default/files/SDRPRules/1May2010/28final/.pdfVersion, diunduh 6 November 2001.

24 Pahroji, "Perbandingan Hukum ketenagakerjaan Negara Malaysia dan Negara Indonesia dalam Perlindungan Hukum dan Penegakan Hak Asasi Manusia",

http://www.unsika.ac.id/sites/default/files/upload/Perbandingan/Sistem/Hukum/Ketenagakerjaan/Negara/M alaysia/dan/Indonesia.pdf.

25 MYnic, “About Mynic”, http://mynic.my/en/about-us.php 19/07/2013, diunduh 19 Juli 2013. 
Helni Mutiarsih Jumhur: Perbandingan Bentuk Kelembagaan Pengelola Nama Domain di Indonesia dengan Lembaga Pengelola Nama Domain di Beberapa Negara

nasional milik Malaysia dan merupakan merek individu yang unik (unique brand identity) di internet. MyNIC mengelola pendaftaran nama domain di antaranya: .com.my, .org.my, .net.my, .edu.my, .gov.my, mil.my, dan .name.my.

\section{b. Fungsi dan Peran MyNIC sebagai Pengelola Nama di Malaysia}

MyNIC adalah satu-satunya badan yang mengelola ccTLD untuk Malaysia. Siapa saja yang ingin mendaftar <.nama domain.my> dapat melakukannya ke MyNIC. MyNIC memiliki aturan atau prosedur yang sangat lengkap dalam pendaftaran nama domain, dan aturan tersebut di publikasi dalam website MyNIC. MyNIC adalah administrator tunggal untuk alamat web yang berakhir dengan .MYNIC. Sebagai tingkat nasional nama domain, MyNIC menyediakan organisasi Malaysia dan individu identitas merek yang unik di Internet.

MyNIC memegang tanggung jawab mengembangkan kebijakan domain tingkat atas dan melaksanakan proyek-proyek penelitian seperti:

1) IPv6 (Internet Protocolversi 6);

2) DNSSEC (Domain Name Server Security Extensions);

3) ENUM (Nomor Telepon Pemetaan);

4) Anycast dan IDN (Mendunia Nama Domain);

5) Mempromosikan dan mengadakan pelatihan kegiatan untuk penggunaan teknologi di atas

MyNIC mengelola delapan (8) kategori nama domain, yaitu:

a) .my: bagi individu dan organisasi Malaysia;

b) .com.my: bagi organisasi/kegiatan komersial;

c) .net.my: bagi organisasi/ kegiatan yang terkait dengan jaringan;

d) .org.my: bagi organisasi/kegiatan yang tidak memenuhi syarat ;

e) .edu.my: bagi organisasi pendidikan Malaysia;

f) gov.my: bagi organisasi Pemerintah Malaysia;

g) .mil.my: bagi organisasi militer Malaysia;

h) .name.my: bagi penggunaan pribadi individu Malaysia.

MyNIC memiliki jaringan reseller nasional yang memperkerjakan 24x7 asisten yang membantu dalam melakukan pendaftaran dan kegiatan penagihan nama domain. Reseller tersebut juga ahli dalam memberikan pelayanan satu atap untuk semua web dan internet kebutuhan. Di antara layanan yang diberikan adalah:

1) pengembangan website;

2) membuat account email;

3) web hosting;

4) desain web;

5) pembaharuan tahunan nama domain.

Selain itu, reseller mereka juga menyediakan service lain yang berhubungan dengan kebutuhan web dan internet. Service lain yang disediakan di antaranya: 
Helni Mutiarsih Jumhur: Perbandingan Bentuk Kelembagaan Pengelola Nama Domain di Indonesia dengan Lembaga Pengelola Nama Domain di Beberapa Negara

1) pengembangan website;

2) membuat account email;

3) web hosting;

4) desain web;

5) pembaharuan tahunan nama domain.

\section{c. Prosedur Pendaftaran Domain Name di MyNIC}

MyNIC adalah satu-satunya badan yang mengelola ccTLD Malaysia. Siapapun yang ingin mendaftar nama domain .my hanya dapat dilakukan di MyNIC. Aplikasi pendaftaran nama domain untuk .edu.my, gov.my, dan .mil.my harus disampaikan secara online melalui sistem online MyNIC. Aplikasi disampaikan melalui e-mail tidak akan dilayani. Aplikasi untuk com.my, .org.my, .net.my, dan <dan nama domain.my> yang harus dilakukan melalui mitra MyNIC secara resmi ditunjuk, yang disebut reseller.

d. Lembaga Penyelesaian Perselisihan Nama Domain di Malaysia: Domain Name Dispute Resolution Policy (MyDRP)

Dalam penyelenggaraannya, lembaga penyelesaian sengketa MyNIC memiliki aturan yang berisi tentang: pertama, MyNIC'S (.my) Domain Name Dispute Resolution Policy (Policy) yang berisi tentang kebijakan dari penyelenggaraan sistem penyelesaian sengketa nama domain; dan kedua, MYNIC'S (.my) Domain Name Dispute Resolution (the Rules) yang berisi aturan yang terkait dengan aturan penyelenggaraan penyelesaian sengketa nama domain.

\begin{tabular}{|c|c|c|c|c|}
\hline & & Australia/auDA & Singapura/SIGNIC & Malaysia/MyNIC \\
\hline 1 & $\begin{array}{l}\text { Bentuk } \\
\text { Lembaga }\end{array}$ & $\begin{array}{l}\text { merupakan badan independen atau } \\
\text { self-regulatory body untuk nama } \\
\text { domain .au, pada bulan Desember } \\
2000 \text {, Pemerintah Australia secara } \\
\text { resmi mengesahkan AuDA sebagai } \\
\text { lembaga yang tepat untuk mengelola } \\
\text { ruang domain.au. }\end{array}$ & $\begin{array}{l}\text { Pada Juni 1997, SGNIC didirikan } \\
\text { sebagai perusahaan terbatas } \\
\text { swasta dan dimiliki sepenuhnya } \\
\text { oleh NCB. SGNIC kemudian } \\
\text { dipindahkan ke IDA. }{ }^{26} \text { ketika } \\
\text { pemerintah menggabungkan } \\
\text { N C B d a n O t o r i t a s } \\
\text { Telekomunikasi Singapura pada } \\
\text { tanggal1 Desember } 1999 \text {. }\end{array}$ & $\begin{array}{l}\text { (badan hukum Berhad MyNIC; } \\
\text { Pendaftaran Perusahaan No: } \\
735031-\mathrm{H} \text { ) adalah lembaga di } \\
\text { bawah Ministry of Science, } \\
\text { Technology and Innovation } \\
\text { (MOSTI) dan diatur oleh } \\
\text { MCMC. }\end{array}$ \\
\hline 2 & $\begin{array}{l}\text { Fungsi dan } \\
\text { Peranan }\end{array}$ & $\begin{array}{l}\text { AuDA adalah administrator untuk } \\
\text { ccTLD.au. }\end{array}$ & $\begin{array}{l}\text { Sebagai registry, SGNIC } \\
\text { beroperasi dan mengontrol } \\
\text { tingkat atas sistem nama } \\
\text { domain internet.sg dan } \\
\text { mengelola pendaftaran (a) nama } \\
\text { domain tingkat ketiga di bawah- } \\
\text { tingkat kedua.com,.org, } \\
\text { net,.edu, .gov. dan per domain, } \\
\text { dan (b) nama domain tingkat } \\
\text { kedua di bawah domain top- } \\
\text { level.Sg. ("SLDs"). }\end{array}$ & $\begin{array}{l}\text { MyNIC adalah administrator } \\
\text { tunggal untuk alamat web yang } \\
\text { berakhir dengan .MYNIC.n } \\
\text { diatur oleh MCMC. }\end{array}$ \\
\hline
\end{tabular}

26 The Infocomm Development Authority of Singapore (IDA),http://www.ida.gov.sg/,The Infocomm Development Authority of Singapore (IDA), a statutory board of the Singapore Government, was formed on 1 December 1999 
Helni Mutiarsih Jumhur: Perbandingan Bentuk Kelembagaan Pengelola Nama Domain di Indonesia dengan Lembaga Pengelola Nama Domain di Beberapa Negara

\begin{tabular}{|c|c|c|c|c|}
\hline 3 & $\begin{array}{l}\text { Prosedur } \\
\text { Pendaftaran }\end{array}$ & $\begin{array}{l}\text { Pendaftar yang ingin mengajukan } \\
\text { pendaftaran nama domain memilih } \\
\text { registrar Anda dan ikuti proses } \\
\text { aplikasi mereka. Beberapa registrar } \\
\text { memberikan pelayanan langsung } \\
\text { kepada masyarakat untuk lebih jelas } \\
\text { lihat daftar registrar AuDA yang sudah } \\
\text { terakreditasi, untuk mengajukan } \\
\text { pendaftaran nama domain gov.au, } \\
\text { Anda harus mengikuti proses yang } \\
\text { tercant um pada we bsite } \\
\text { http://www.domainname.gov.au/ } \\
\text { dan untuk mengajukan nama domain } \\
\text { edu.au, Anda dapat mengikuti } \\
\text { petunjuk yang tercantum dalam } \\
w \quad e \quad b \quad s \quad i \quad t \quad e \\
\text { http://www.domainname.edu.au/. }\end{array}$ & $\begin{array}{l}\text { Dalam proses pengajuan nama } \\
\text { domain SGNIC memiliki aturan } \\
\text { kebijakan yakni Registration } \\
\text { Policies, Procedures and } \\
\text { Guidelines (RPPG). }\end{array}$ & $\begin{array}{l}\text { Aplikasi Pendaftaran dilakuka } \\
\text { secara online. }\end{array}$ \\
\hline 4 & $\begin{array}{l}\text { Lembaga } \\
\text { Penyelesaian } \\
\text { Perselisihan }\end{array}$ & & $\begin{array}{l}\text { SDRP adalah kebijakan yang } \\
\text { m en etapkan ke rang ka } \\
\text { pengaturan tentang bagaimana } \\
\text { perselisihan antara registrant } \\
\text { dan pihak (selain SGNIC) atas } \\
\text { pendaftaran dan penggunaan } \\
\text { nama domain. } 5 \text { milik } \\
\text { registrant diselesaikan. }\end{array}$ & $\begin{array}{l}\text { MyDRP disediakan oleh MyNIC } \\
\text { yang berfungsi untuk } \\
\text { menyelesaikan sengketa } \\
\text { pemiliknamadomain. }\end{array}$ \\
\hline
\end{tabular}

\section{Lembaga Pengelolaan dan Pendaftaran Nama Domain di Indonesia}

Lembaga Pengelola Nama Domain di Indonesia sebenarnya telah memiliki bentuk yang sesuai dengan peraturan internasional yang dikeluarkan oleh ICANN yakni pengelola nama domain adalah lembaga nirlaba diberi kewenangan untuk mengelola dirinya sendiri sehingga lembaga tersebut diperbolehkan mengeluarkan peraturan sebagai aturan main dalam pengelolaan dan pendaftaran nama domain. ${ }^{27}$ Namun syaratnya adalah peraturan tersebut harus sesuai dengan peraturan internasional dan peraturan perundang-undangan di Indonesia. ${ }^{28}$

when the government merged the National Computer Board (NCB) and Telecommunication Authority of Singapore (TAS), as a result of a growing convergence of information technology and telephony. IDA aims to grow Singapore into a dynamic global infocomm hub and to infocomm for Singapore's economic and social development.

27 PANDI, "Sejarah PANDI", http://www.pandi.or.id/ diunduh 5 Juni 2012.

28 Selain itu karena di Indonesia Nama Domain termasuk bagian industri strategis bagi negara maka harus ada keterkaitan antara peran pemerintah dengan lembaga pengelola pendaftaran nama domain tersebut. Pemerintah Indonesia dapat mengadopsi cara beberapa negara melakukan pengendalian tentang lembaga nama domain tersebut dengan cara mendelegasikan kepemilikan dan kewenangan pemerintah kepada lembaga pengelola pendaftaran nama domain. 
Helni Mutiarsih Jumhur: Perbandingan Bentuk Kelembagaan Pengelola Nama Domain di Indonesia dengan Lembaga Pengelola Nama Domain di Beberapa Negara

Selanjutnya kedudukan pemerintah dalam lembaga pengelola pendaftaran nama domain di Indonesia seharusnya sesuai dengan kebijakan yang dikeluarkan ICANN bahwa negara hanya berperan sebagai lembaga Advisor yang bertugas memberikan pertimbangan pengelolaan nama domain dan memberikan perlindungan kepada para pengguna nama domain. Pembentukan lembaga advisory tersebut dapat diinisiasi oleh pemerintah dengan menunjuk menteri terkait untuk menjadi ketuanya. Hal ini sudah diatur dalam peraturan menteri bahwa pengelola nama domain harus mendapat rekomendasi dari forum nama domain, forum ini beranggotakan unsur pemerintah dan unsur perwakilan dari asosiasi. Oleh karena peraturan menteri (selanjutnya disebut sebagai Permen) ini baru saja keluar di tahun 2013, maka pengaturan, dalam proses pembentukan PANDI belum sesuai dengan prosedur yang ditetapkan dalam peraturan menteri tersebut, tetapi dalam permen tersebut diberikan kesempatan selama satu tahun untuk melakukan penyesuaian proses pembentukan lembaga pengelola nama domain di Indonesia agar sesuai dengan peraturan yang telah ditetapkan dalam peraturan perundang-undangan di Indonesia.

Dalam pembentukan lembaga nama domain tersebut, substansi yang harus diperjelas adalah tentang kedudukan nama domain sebagai bagian dari industri teknologi informasi/telematika, yaitu tentang kedudukan industri tersebut sebagai industri yang strategis bagi negara. Artinya, jika semua pihak mengakui industri telematika merupakan industri yang strategis bagi negara maka pemilik industri tersebut adalah negara sehingga secara otomatis nama domain juga merupakan subjek yang dimiliki oleh negara. Hal tersebut memberikan konsekuensi bahwa segala pengaturan tentang pengelolaan nama domain harus dilakukan oleh negara. Namun berdasarkan UU ITE, negara sudah memberikan ruang kepada semua pihak bahwa pengelola nama domain adalah masyarakat atau pemerintah. Artinya pemerintah sendiri telah memberikan ruang bahwa pengelolaan dan pendaftaran nama domain adalah lembaga yang dibentuk dan dikelola oleh masyarakat asalkan pembentukan lembaga tersebut sesuai dengan proses dan prosedur yang ditetapkan dalam peraturan perundang-undangan di bawahnya.

Diawali dari peraturan yang ada dalam UU ITE disebutkan bahwa nama domain merupakan alamat internet yang dapat dimiliki oleh perseorangan, badan hukum, atau negara. Badan pengelola nama domain dapat dibentuk oleh masyarakat dan atau pemerintah, sementara itu pendaftar nama domain dilakukan dengan asas "first come first serve" yaitu pendaftar pertama yang akan mendapatkan hak atas nama domain tersebut. Dalam PPSTE lebih diuraikan lagi bahwa para pihak dari pengelolaan dan pendaftaran nama domain terdiri dari: 1) Registry yaitu pihak yang mengelola nama domain; 2) Registrar yaitu pihak yang diberikan hak untuk melakukan pendaftaran nama domain; 3) pengguna nama domain yaitu pihak yang 
Helni Mutiarsih Jumhur: Perbandingan Bentuk Kelembagaan Pengelola Nama Domain di Indonesia dengan Lembaga Pengelola Nama Domain di Beberapa Negara

dapat melakukan pendaftaran nama domain yaitu perseorangan, badan usaha, atau negara.

Dalam Permen tentang domain diatur lebih terurai lagi yaitu para pihak dalam pengelolaan dan pendaftaran nama domain diatur lebih detail lagi, di mana masingmasing pihak memiliki prosedur, tugas, dan kewenangan masing-masing sesuai dengan peraturan yang ada. Diawali dari pengertian pengelola nama domain yang terdiri atas registry dan registrar di mana registry diberikan hak untuk mengelola nama domain tingkat generik dan nama domain tingkat tinggi Indonesia, sementara registrar diberikan hak oleh registry untuk melakukan pendaftaran kedua tingkat nama domain tersebut. Tugas utama dari registry adalah: 1) melakukan masukan terhadap pengaturan dari nama domain; 2) melakukan pengawasan terhadap pendaftaran nama domain; 3) menyelesaikan perselisihan nama domain.

Selanjutnya dijelaskan lagi bahwa pembentukan dari pengelola nama domain (registry) harus berdasarkan rekomendasi dari forum Nama Domain Indonesia yang terbentuk dari perwakilan pemerintah, pakar, dan perwakilan asosiasi /perwakilan organisasi yang terkait dengan pengelolaan nama domain di Indonesia. Karena peraturan perundang-undangan yang secara teknis mengatur tentang pembentukan lembaga nama domain baru keluar setelah lembaga PANDI berdiri maka implementasi dari peraturan tersebut harus disesuaikan dengan keberadaan lembaga pengelola nama domain yang sudah ada. Hal tersebut juga dikarenakan lembaga pengelola nama domain yang sudah ada telah memiliki peraturanperaturan yang dibuat dalam bentuk kebijakan PANDI yang dijadikan acuan dalam pengelolaan nama domain di Indonesia. Meskipun peraturan-peraturan tersebut keluar sebelum peraturan dibawah UU ITE dibuat dan diterbitkan oleh pemerintah tetapi peraturan tersebut sudah sesuai dengan UU ITE dan peraturan internasional tentang pengelolaan nama domain di suatu negara.

Dalam Permen disebutkan bahwa masa peralihan untuk penyesuaian implementasi Permen diberikan waktu selama satu tahun, dan dalam waktu tersebut dapat dilakukan evaluasi dan penyesuaian-penyesuaian antara peraturan yang telah dibuat oleh pemerintah dengan peraturan yang telah dibuat oleh PANDI. Dalam penelitian ini hal yang menjadi pokok permasalahan adalah mencari bentuk yang ideal dari lembaga pengelola nama domain di Indonesia yang sesuai dengan peraturan internasional dan peraturan nasional.

Melihat ketidakpastian dalam pengaturan tentang pengelolaan nama domain di Indonesia, dalam penelitian ini penulis melakukan studi banding dengan negara yang telah memiliki lembaga pengelola nama domain (registry) dan memiliki kebijakan tentang pengelolaaan dan pembentukan kelembagaan nama domain. Salah satu negara yang penulis pilih untuk dijadikan model pengelolaan nama domain adalah negara Australia dengan nama registry.AuDA. 
Helni Mutiarsih Jumhur: Perbandingan Bentuk Kelembagaan Pengelola Nama Domain di Indonesia dengan Lembaga Pengelola Nama Domain di Beberapa Negara

AuDA dibentuk berdasarkan perintah dari negara dan peraturan dari pengelolaan nama domain berdasarkan prinsip-prinsip yang ada dalam UU Telekomunikasi di Australia. AuDA berperan sebagai ccTLD bagi Australia sehingga melalui ccTLD pemerintah. Pemerintah tidak membuat peraturan secara detail tentang pengelola dan pendaftaran nama domain di Australia melainkan pemerintah memberikan kekuasaan kepada AuDA untuk membuat kebijakan berupa rules dan policy tentang pengaturan nama domain. Kebijakan tersebut harus mengacu kepada UU Telekomunikasi Australia dan peraturan yang ditetapkan ICANN. AuDA tidak melakukan pendaftaran nama domain secara langsung melainkan memberikan kesempatan kepada pihak swasta untuk menjadi registrar, tetapi lembaga registrar tersebut harus memenuhi standar akreditas yang ditetapkan AuDA. Jika registrar memenuhi standar maka AuDA akan memberikan lisensi kepada registrar untuk pengelolaan nama domain dan juga menyelenggarakan proses penyelesaian sengketa para pengguna nama domain. Sistem akreditasi ini merupakan cara pemerintah melakukan fungsi pengendalian tanpa melanggar prinsip-prinsip internasional yang dikeluarkan oleh ICANN. Melalui proses akreditas ini maka pemerintah melalui AuDA dapat mencabut izin registrar yang melanggar syarat dan ketentuan pengelolaan dan penyediaan jasa pendaftaran nama domain di Australia.

Proses pendaftaran nama domain yang disediakan oleh registrar sangat mudah dimana para pengguna yang bermaksud mendaftarkan nama domain dapat melakukan pendaftaran secara online, dengan memasukkan semua aplikasi yang menjadi prasyarat. Registrar akan melakukan verifikasi dalam jangka waktu beberapa hari, ketika pendaftar nama domain mendapatkan persetujuan tentang penggunaan nama domain yang diajukan maka bersamaan dengan itu pengguna nama domain sudah dianggap tunduk kepada ketentuan yang sudah ditetapkan oleh registrar yaitu tentang ketentuan pendaftaran nama domain, ketentuan pengguna nama domain, dan ketentuan tentang penyelesaian sengketa nama domain. Jadi, jika suatu hari terjadi perselisihan antara pengguna nama domain atau antara pengguna nama domain dengan registrar maka para pihak secara otomatis harus menyelesaikan sengketa melalui lembaga sengketa di luar pengadilan atau ADR. Lembaga ADR ini disediakan oleh registrar dan keputusannya bersifat final dan binding artinya ketika sengketa sudah diputuskan dalam forum sengketa tersebut maka para pihak tidak boleh melakukan upaya lain.

Pengaturan pengelola nama domain oleh AuDA sangat praktis, mudah, dan sederhana sehingga memberi kemudahan kepada para pihak terutama para pengguna domain di Australia. Selain itu karena pemerintah tidak terlalu intervensi dalam proses dan pengaturan pengelolaan nama domain di Australia, maka keseluruhan peraturan dan kebijakan yang dikeluarkan oleh registry/AuDA dapat dilakukan dengan efektif. Hal ini telah memberikan kepastian hukum bagi para pengguna nama domain baik bagi individu maupun perusahaan. 
Helni Mutiarsih Jumhur: Perbandingan Bentuk Kelembagaan Pengelola Nama Domain di Indonesia dengan Lembaga Pengelola Nama Domain di Beberapa Negara

\section{Penutup}

Dengan melihat beberapa bentuk lembaga pengelola nama domain di ketiga negara yang dikemukakan penulis maka Indonesia dapat mengacu kepada lembaga pengelola nama domain Australia yaitu auDA karena auDA memiliki bentuk organisasi yang mengombinasikan antara peranan pemerintah dan swasta dalam pengelolaan nama domain sehingga bentuk tersebut sesuai dengan keadaan dan posisi nama domain di Indonesia. Diharapkan dengan mendapatkan contoh bentuk pengelola nama domain di negara lain yang cocok dengan karakteristik sistem pengelolaan nama domain di Indonesia, pemerintah dapat membuat peraturan perundang-undangan yang melindungi kepentingan semua pihak.

\section{Daftar Pustaka}

\section{Buku}

Ronny Hanitijo Soemitro, Metodologi Penelitian Hukum dan Jurumetri, Ghalia, Jakarta, 1994.

\section{Dokumen Lain}

AuDA, "AuDA History", http://www.ausregistry.com.au/role-of-the-registry, diunduh tanggal 20 Oktober 2013.

, "About AuDA", http://www.AuDA.org.au/about-AuDA/, diunduh tanggal 15 Juli 2013.

, "Strategic Plan",http://www.AuDA.org.au/about-AuDA/our-org/strategicplan/, diunduh tanggal 20 September 2012.

".au Dispute Resolution Policy (auDRP)"

http://www.AuDA.org.au/policies/current policies/2010-05/

"Strategic Planning",http://www.AuDA.org.au/about-AuDA/ourorg/strategic-plan, diunduh Juli 2012

Bender, Mark,"What's in a Name: Domain Name Disputes Involving Trademarks in Australia", http://papers.ssrn.com/sol3/papers.cfm?abstract_id=1091066, diunduh tanggal 15 Juli 2013.

Mynic, "About Mynic", http://mynic.my/en/about-us.php 19/07/2013, diunduh pada tanggal 19 Juli 2013

Pahroji, "Perbandingan Hukum ketenagakerjaan Negara Malaysia dan Negara Indonesia Dalam Perlindungan Hukum dan Penegakan Hak Asasi Manusia", http://www.unsika.ac.id/sites/default/files/upload/Perbandingan/Sistem/Huk um/Ketenagakerjaan/Negara/Malaysia/dan/Indonesia.pdf, diunduh tanggal 20 Juli 2012. 
PANDI, "Sejarah PANDI", http://www.pandi.or.id/, diunduh tanggal 5 Juni 2012.

RindaAmalia, "Sistem Hukum Singapura", http://www.google.com/ rindaamalia.dosen.narotama.ac.id/Ffiles/F2013/F07/FKuliah-10-SistemHukum-Singapura.

SGNIC,"SGNIC, Singapore Domain Name Dispute Resolution Policy (SDRP) Policy",http://www.sgnic.sg/sites/default/files/SDRPRules/1May2010/28final/. pdf Version 1, diunduh pada tanggal 6 November 2001.

, "Mission Statement", http://www.sgnic.sg/page/mission-statement, diunduh pada tanggal 21 Juli 2012.

, "History", http://www.sgnic.sg/page/history-sgnic, diunduh pada tanggal 17 Juli 2013.

, "Mission Statement", http://www.sgnic.sg/page/mission-statement, diunduh pada tanggal 21 Juli 2012.

, The Infocomm Development Authority of Singapore (IDA), http://www.ida.gov.sg/, diunduh pada tanggal 12 Juli 2012. 